\author{
Коваленко Н.О. \\ кандидат технічних наук, доцент \\ кафедра готельно-ресторанного бізнесу \\ Одеська національна академія харчових технологій \\ вул. Канатна, 112, г. Одеса, Україна, 65039 \\ E-mail: postfornatalia@gmail.com
}

\title{
АНАЛІЗ РИНКУ САНАТОРНО-КУРОРТНИХ ПОСЛУГ УКРАЇНИ
}

Розглянуто нормативно-правове забезпечення санаторно-курортної галузі України. Розглянуто класифрікацію санаторно-курортних закладів. Досліджено тенденції зміни санаторно-курортної галузі у 2010-2014 роках. Наведено економічні ефекти впливу ринку санаторно-курортних послуг на економіку держави. Представлено фрактори, які впливають на ринок санаторно-курортних послуг. Запропоновано ряд заходів щодо ефективного використання потенційних можливостей ринку санаторно-курортних послуг.

Ключові слова: ринок санаторно-курортних послуг, санаторно-курортні заклади, фінансове забезпечення, інвестування, податкове регулювання.

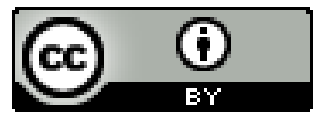

This work is licensed under a Creative Commons Attribution 4.0 International License http://creativecommons.org/licenses/by/4.0/
Постановка проблеми та її зв'язок $з$ важливими науковими та практичними завданнями. В Україні ринок санаторно-курортних послуг представлений широким спектром послуг, що обумовлено постійною потребою в них. Природньо-кліматичні умови сприяють розвитку даного ринку, однак існує змінний характер рівня запотребованості послуг санаторно-курортних закладів, що спричинено впливом різного виду факторів. Попри це ринок санаторнокурортних послуг є важливим для економічного розвитку держави, тому дослідження даної проблематики викликає значну зацікавленість в наукових колах.

Аналіз останніх публікацій по проблемі. Дослідження стану ринку санаторно-курортних послуг в Україні та функціонування санаторнокурортних закладів проводили такі науковці: Вуйцик О., Чорненька Н., Воробйов Ю., Давидова О., Халіна I., Несторенко Т., Мігущенко Ю., Зятковський І., Гуменюк В. та інші. Однак змінний характер тенденцій на ринку та впливу різноманітних чинників на його розвиток обумовлює необхідність подальшого дослідження даної проблематики.

Формулювання цілей дослідження. Мета дослідження полягає в проведенні аналізу сучасного стану ринку санаторно-курортних послуг в Україні, визначенні недоліків функціонування санаторнокурортних закладів та розробці рекомендацій для покращення їх діяльності в перспективі.

Виклад основних результатів та їх обгрунтування. Одним із пріоритетних ринків та напрямів розвитку держави в економічно розвинутих країнах $\epsilon$ ринок санаторно-курортних послуг. Це зумовлено не тільки економічною складовою, яка формується внаслідок надання послуг на ньому, але також і прове- деннням оздоровчих заходів, які надають можливість покращити ситуацію у сфері охорони здоров'я в державі. Україна $є$ дуже привабливою для споживачів санаторно-курортних послуг, адже, як зазначає Вуйцик О. «Україна посідає одне 3 провідних місць в Свропі щодо забезпечення курортними лікувальними ресурсами, в тому числі такими унікальними, як кліматичні зони морського узбережжя та Карпат, а також мінеральні води та лікувальні грязі практично всіх відомих бальнеологічних типів» [1].

Процес надання послуг споживачам в Україні регулюється багатьма нормативно-правовими актами до яких відносять: Конституцію України (Стаття 42), Цивільний Кодекс України (Статті 901-907), Закон України «Про захист прав споживачів» (Статті 10, 12 $13,17,20)$ та Постанови Кабінету Міністрів України (№313 від 16.05.1994, №1248 від 21.12.2005, №903 від 10.11.1995, №684 від 1.09.2003, №720 від 09.09.2005 та ін.). Правовим організаційним та соціальноекономічним підгрунтям, на якому базується надання послуг санаторно-курортними закладами в Україні $\epsilon$ Закон України «Про курорти» від 5.10.2000 (зі змінами та доповненнями).

Згідно Закону України «Про курорти», «санаторно-курортні заклади - це заклади охорони здоров'я, що розташовані на територіях курортів і забезпечують подання громадянам послуг лікувального, профілактичного та реабілітаційного характеру з використанням природних лікувальних ресурсів» [2].

В науковій літературі $є$ багато класифікацій санаторно-курортних закладів. Наведемо узагальнену класифікацію закладів ринку санаторно-курортних послуг України в таблиці 1. 
Узагальнена класифікація закладів ринку санаторно-курортних послуг України*

\begin{tabular}{|c|c|}
\hline Класифікаційна ознака & Підвид \\
\hline Профіль & Однопрофільні (монопрофільні); багатопрофільні. \\
\hline Спеціалізація & Загальнотерапевтичні; спеціалізовані (санаторії). \\
\hline Тип & $\begin{array}{l}\text { Санаторії та пансіонати з лікуванням; санаторії-профілакторії; } \\
\text { будинки і пансіонати відпочинку; бази та інші заклади відпо- } \\
\text { чинку; дитячі оздоровчі табори. }\end{array}$ \\
\hline Функція & Лікувальні; оздоровчі. \\
\hline Період функціонування & Цілорічні; сезонні. \\
\hline Цільовий сегмент & Для дорослих; для дорослих з дітьми; для дітей. \\
\hline Місце розташування & Курортного типу; некурортного типу. \\
\hline Термін перебування & 1-2 - денне; тривале - 3 дні й більше; тривале й 1-2 - денне. \\
\hline Форма власності & $\begin{array}{l}\text { Приватне підприємство; підприємство колективної власності; } \\
\text { комунальне підприємство; державне підприємство; змішаної } \\
\text { форми власності. }\end{array}$ \\
\hline Мета та характер комерційної діяльності & Комерційні; некомерційні. \\
\hline Організаційно-правова форма & $\begin{array}{l}\text { Акціонерне товариство; товариством з обмеженою відповіда- } \\
\text { льністю; товариством } 3 \text { додатковою відповідальністю; повне } \\
\text { товариство; командитне товариство. }\end{array}$ \\
\hline Правовий та економічний статус & $\begin{array}{l}3 \text { повною правовою та економічною самостійністю; дочірні } \\
\text { підприємства; філіали; представництва; відокремлені підроз- } \\
\text { діли. }\end{array}$ \\
\hline
\end{tabular}

* складено автором

Наведена узагальнена класифікація дозволяє сформувати структуру закладів ринку санаторнокурортних послуг України.
Класифікація курортів за напрямом оздоровлення з врахуванням географічного розміщення наведено в таблиці 2.

Таблиця 2

Класифікація курортів за напрямом оздоровлення та врахуванням географічного розміщення*

\begin{tabular}{|c|c|}
\hline Географічне розміщення & Класифікація курортів \\
\hline Вінницька область & Бальнеологічні. \\
\hline Донецька область & Кліматичні, бальнеологічні. \\
\hline Закарпатська область & Бальнеологічні. \\
\hline Запорізька область & Кліматичні, бальнеогрязеві. \\
\hline Івано-Франківська область & Кліматичні, бальнеогрязеві. \\
\hline Київська & Кліматичні, бальнеологічні. \\
\hline Львівська & Бальнеологічні. \\
\hline Миколаївська & Кліматичні. \\
\hline Одеська & Кліматичні, бальнеогрязеві. \\
\hline Полтавська & Бальнеологічні. \\
\hline Харківська & Бальнеологічні. \\
\hline Херсонська & Кліматичні, бальнеогрязеві. \\
\hline
\end{tabular}

* складено автором

Як видно з таблиці 2, за напрямом оздоровлення населення та географічним розташуванням ринок санаторно-курортних послуг України представлений різноманітним спектром закладів, які спеціалізуються наданням повного спектру послуг та забез- печенням споживачів природними лікувальними ресурсами.

Основним видом послуг, які надаються на ринку санаторно-курортного комплексу є сукупність заходів направлених на оздоровлення людини. Поряд 3 цією послугою, санаторно-курортними закладами 
надаються супутні послуги, які взаємопов'язані і реалізовуються паралельно з оздоровленням. До таких послуг відносять сукупність заходів, які стосуються задоволення побутових потреб споживача, культурно-розважальні заходи та послуги з надання якісного харчування.
Станом на кінець 2014 року в Україні діяло 58 курортів, які за своєю специфікацією здійснюють надання, як споріднених за своєю суттю і якостями послуги так і відмінні, що залежать від потреб споживача. Динаміка зміни кількості санаторнокурортних та оздоровчих закладів має змінний характер (табл. 3).

Санаторно-курортні та оздоровчі заклади [3]

\begin{tabular}{|c|c|c|c|c|c|c|c|c|c|c|}
\hline \multirow{2}{*}{ Роки } & \multicolumn{2}{|c|}{$\begin{array}{c}\text { Санаторії } \\
\text { та пансіонати з } \\
\text { лікуванням² }\end{array}$} & \multicolumn{2}{|c|}{$\begin{array}{c}\text { Санаторії- } \\
\text { профілакторії² }\end{array}$} & \multicolumn{2}{|c|}{$\begin{array}{c}\text { Будинки } \\
\text { та пансіонати } \\
\text { відпочинку }{ }^{2}\end{array}$} & \multicolumn{2}{|c|}{$\begin{array}{c}\text { Бази та інші } \\
\text { заклади } \\
\text { відпочинку }\end{array}$} & \multicolumn{2}{|c|}{$\begin{array}{c}\text { Дитячі оздоровчі } \\
\text { табори }^{3}\end{array}$} \\
\hline & всього & $\begin{array}{c}\text { у них } \\
\text { ліжок, } \\
\text { тис. }\end{array}$ & вСьОГО & $\begin{array}{c}\text { у них } \\
\text { ліжок, } \\
\text { тис. }\end{array}$ & всього & $\begin{array}{c}\text { у них } \\
\text { місць, } \\
\text { тис. }\end{array}$ & всього & $\begin{array}{c}\text { у них } \\
\text { місць, } \\
\text { тис. }\end{array}$ & всього & $\begin{array}{c}\text { У них } \\
\text { місць, } \\
\text { тис. }\end{array}$ \\
\hline 2010 & 510 & 141 & 234 & 19 & 290 & 60 & 1920 & 217 & 17342 & 196 \\
\hline 2011 & 508 & 141 & 224 & 19 & 280 & 59 & 1947 & 216 & 17703 & 194 \\
\hline 2012 & 484 & 133 & 185 & 18 & 286 & 60 & 1925 & 208 & 17744 & 188 \\
\hline 2013 & 477 & 132 & 165 & 15 & 271 & 57 & 1916 & 202 & 18549 & 191 \\
\hline $2014^{1}$ & 320 & 79 & 118 & 17 & 90 & 17 & 1400 & 157 & 13977 & 126 \\
\hline
\end{tabular}

${ }^{1}$ Без урахування тимчасово окупованої території Автономної Республіки Крим, м. Севастополя та частини зони проведення антитерористичної операції.

${ }^{2}$ у 2002-2011 роках інформація стосовно діяльності санаторно-курортних (оздоровчих) закладів подається за 12 місяців: 31 жовтня попереднього по 30 вересня звітного року.

${ }^{3}$ Починаючи з 2010 року - дитячі заклади оздоровлення та відпочинку.

Протягом останніх п'яти років, кількість санаторно-курортних та оздоровчих закладів має тенденцію до зменшення через нестабільну фінансову ситуацію на внутрішньому ринку країни. В 2014 році одним 3 чинників, який вплинув на зниження кількості закладів, які надають послуги на ринку санаторнокурортного обслуговування і відповідно через який відбулось зменшення кількості оздоровлених у цих закладах людей, стала окупація АРК Крим, де знаходилась значна кількість оздоровчих комплексів, і куди направлялась, через профспілкові путівки, левова частка відпочиваючих. Аналогічна ситуація відбулась на сході України, а саме частини Донецької та Луганської областей, де у зв'язку 3 антитерористичною операцією припинено функціонування багатьох закладів оздоровчого типу.

Змінною також $є$ кількість осіб, які отримали послуги в закладах санаторно-курортного комплексу (рис. 1). Найбільша кількість людей, які відпочивали і оздоровлювались протягом 2011-2014 рр. перебувала в санаторіях та базах відпочинку. Найменшою популярністю користувались заклади 1-2 денного перебування. Загалом динаміка зміни попиту на послуги $є$ негативно, якщо в 2010-2011 рр. кількість споживачів послуг складала 2942 тис. осіб, то у 2014 році - 2173 тис. осіб, що на 662 тис. осіб менше $(-22,5 \%)$ ніж у 2010-2011 рр. Основними причинами даної тенденції можна назвати ряд чинників: збільшення вартості послуг на ринку санаторно-курортного комплексу та інших супутніх послуг пов'язаних 3 ним; зменшення реальних доходів населення через зростаючі темпи інфляції; зниження замовлень на дані послуги з боку профспілок всіх рівнів та зменшення їх фінансування зі сторони держави.

Важливе значення при функціонуванні ринку санаторно-курортних послуг в Україні є його економічна складова, оскільки стан ринку санаторнокурортних послуг взаємопов'язаний 3 економічними процесами, які відбуваються в країні. Як вже зазначалося, фінансовий спад в країні призводить до негативних тенденцій розвитку даного ринку, і навпаки. В той самий час покращення функціонування ринку санаторно-курортних послуг впливає на розвиток економіки. Чорненька Н. В. вважає, що вплив ринку санаторно-курортних послуг на економіку держави має три основних ефекти [4]:

- прямий ефект - доходи санаторнокурортних закладів, туристичних агентств, закладів харчування, історико-культурних об'єктів та інших підприємств туристичної індустрії, а також доходи магазинів від покупок, що їх здійснюють відпочиваючі;

- непрямий ефект - доходи будівельних організацій, банків, постачальників харчів, комунальних служб, отриманих ними від реалізації продукції та послуг, що забезпечують комфортне перебування відпочиваючих у санаторно-курортних закладах;

- індукований ефект - доходи інших місцевих резидентів у вигляді заробітної плати, дивідендів, орендної плати та інших видів платежів, отриманих ними від реалізації продукції та послуг усім суб'єктам, котрі причетні до санаторно-курортної діяльності. 


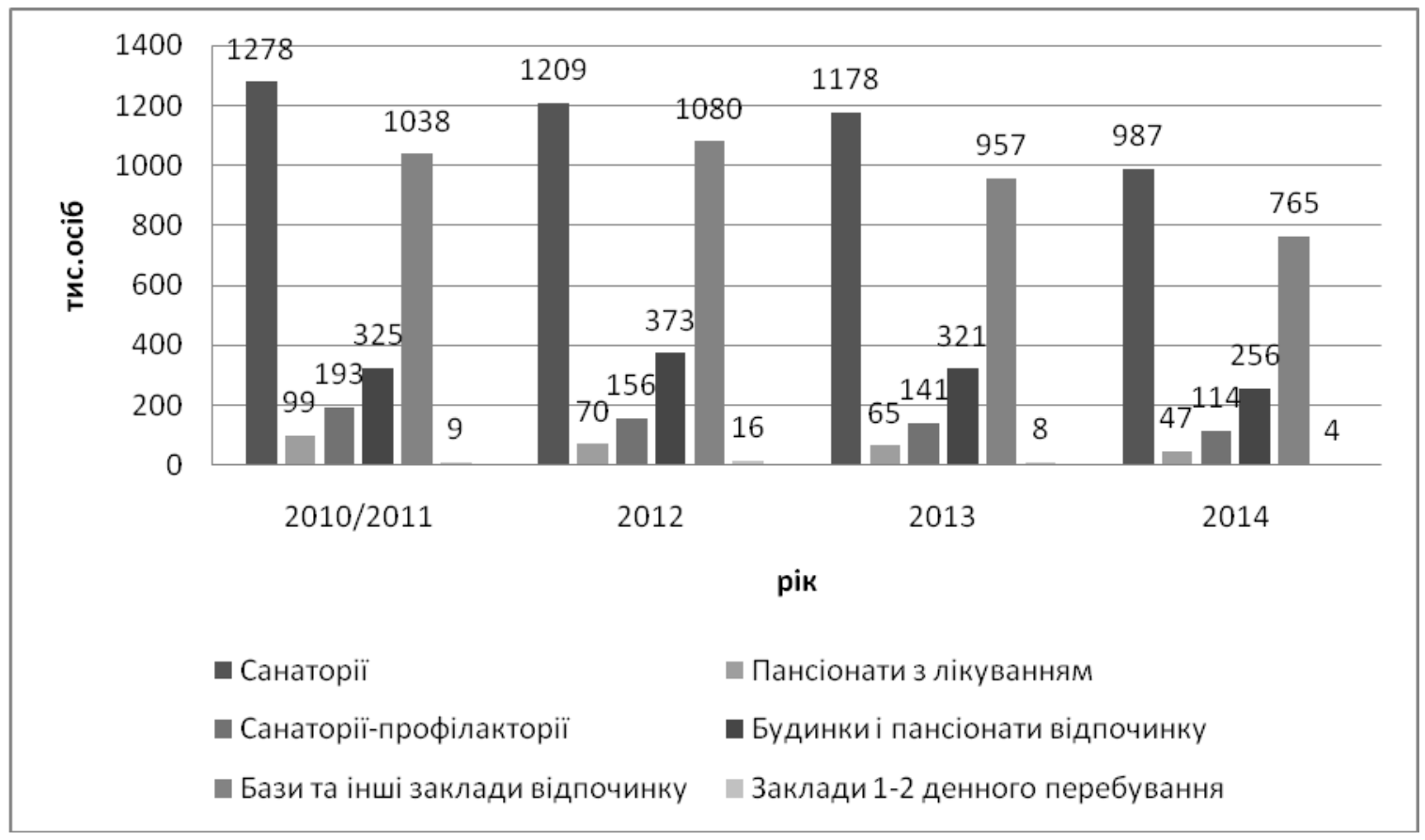

Рис. 1. Кількість осіб, оздоровлених в закладах санаторно-курортного комплексу, тис. осіб *

* складено автором

На сьогоднішній день, основними факторами, які стримують розвиток ринку санаторно-курортних послуг в Україні можна назвати такі:

- негативний імідж українських курортних зон зі сторони іноземних туристів;

- слабке, а інколи відсутнє рекламне позиціонування українських курортів та послуг, які вони надають на міжнародному ринку туристичних послуг;

- слабо розвинута і застаріла санаторнокурортна інфраструктура, яка не може в повній мірі задовольняти сучасні потреби споживачів;

- низька якість послуг і недостатній рівень обслуговування, які надаються в курортних зонах в порівнянні $з$ аналогічними показниками зарубіжних курортів;

- значна конкуренція на ринку, між санаторними закладами державного і приватного сектору в курортних зонах;

- недостатній рівень державного сприяння розвитку ринку санаторно-курортних послуг;

- незначна кількість інвестицій в об'єкти ринку санаторно-курортних закладів.

Одним із ключових факторів, які впливають на розвиток ринку санаторно-курортних послуг $\epsilon$ фінансове забезпечення закладів, яке грунтується на основі різноманітних джерел і форм формування, поділу і використання грошових коштів.

До основних джерел фінансового забезпечення санаторно-курортних закладів можливо віднести [5]: кошти державного бюджету; кошти місцевих бюджетів; кошти Фонду соціального страхування; благодійні внески; кошти від продажу путівок юридичним і фізичним особам; кошти власників санатор- но-курортних закладів; позикові кошти у вигляді кредитів та різних позик; кредиторська заборгованість за товари, послуги, роботи; кредиторська заборгованість за розрахунками; інші джерела фінансового забезпечення.

Найпоширенішим видом фінансового забезпечення санаторно-курортних закладів в Україні $€$ кошти державного і місцевого бюджетів, оскільки основна частина цих закладів знаходиться у власності держави або місцевих громад. Заклади, які знаходяться у приватній власності фінансуються за рахунок виключно власних або залучених фінансових ресурсів. Тому важливим аспектом функціонування закладів, які здійснюють надання санаторно-курортних послуг є отримання прибутку. Для забезпечення прибутковості санаторно-курортних закладів потрібно здійснювати аналіз ринку курортних послуг, розширювати їх наявний сегмент та проводити зважену цінову політику для ефективнішого залучення споживачів.

Цінова політика є одним із основних факторів, який формує зацікавленість ринком санаторнокурортних послуг в Україні і яка залежить не тільки від переліку надаваних послуг і сезонності відпочинку але й від ряду інших факторів. Так, попит на курортно-рекреаційні послуги також залежить від рівня доходів споживачів, тому необхідно постійно стежити за тенденціями змін у сфері особистих доходів населення [6]. Скорочення реальних доходів населення в умовах високої інфляції негативно позначається на попиті на послуги закладів санаторно-курортної сфери [3]. Як зазначає Несторенко Т. П., в умовах фінансової кризи також скорочується попит на послу- 
ги санаторно-курортних закладів з боку іноземних клієнтів. Це вимагає від менеджменту санаторіїв приділяти більше уваги оптимізації стратегії ціноутворення [7].

Тому однією $з$ рекомендацій щодо покращення функціонування ринку санаторно-курортних послуг в Україні $є$ врахування принципів та застосування стратегії ціноутворення, врахування і застосування яких дозволить закладам санаторно-курортного комплексу поліпшити результати своєї господарської діяльності та дозволить збільшити перелік та покращити якість надаваних ними послуг.

Значною складовою результативного функціонування та розвитку ринку санаторно-курортних послуг $є$ залучення інвестицій для розбудови курортних комплексів. Як зазначає Мігущенко Ю. В., «ефективність функціонування курортних комплексів та ринку санаторно-курортних послуг напряму пов'язана з реалізацією крупних комплексних інвестиційних проектів. Такі проекти стосуються спортивної, розважальної, лікувально-оздоровчої, конгресної бази курорту, зокрема побудови нових басейнів, тенісних кортів, розважальних комплексів, ресторанів, дискотек, оздоровчих центрів, конгрес-холів та залів» [8].

Не зважаючи на інвестиційну привабливість ринку санаторно-курортних послуг України, обсяг інвестування в цю галузь є недостатнім. Основними джерелами інвестування на даний час виступають кошти, які виділяє держава для державних закладів та фінансові ресурси власників приватних закладів. Однак для збільшення рівня інвестицій в розвиток ринку санаторно-курортних послуг необхідно розробляти i впроваджувати заходи для залучення великих інвесторів. Такими заходами повинні стати:

- розробка та презентація програм для інвесторів щодо потенційних можливостей ринку;

- здійснення прозорої процедури відбору інвесторів та надання гарантій ефективності використання інвестиційних коштів;

- проведення державними органами влади ефективного процесу регулювання діяльності на ринку санаторно-курортних послуг.

При регулюванні функціонування ринку санаторно-курортних послуг в Україні вагоме значення має оподаткування. Податкове регулювання ринку санаторно-курортних послуг пов'язане із вилученням частини підприємницького прибутку в бюджет. У зв'язку із цим держава привласнює частину прибутку, застосовуючи такі два канали їх вилучення, як:

- сплата майнових податків, зокрема внесення податку за землю, рентних платежів;

- внесення суб'єктами господарювання податку на прибуток до бюджету. [9]. Також виробництво санаторно-курортних послуг пов'язане з використанням природно-рекреаційних ресурсів - складової національного багатства - надр України. Сучасне пода- ткове регулювання їх використання здійснюється через застосування загальнодержавного обов'язкового платежу, що має рентний характер, - плати за користування надрами [10].

При залученні інвестицій на ринок санаторно-курортних послуг держава може використовувати метод податкового стимулювання, який включає такі заходи: зменшення податкового навантаження; повне звільнення від податків протягом певного періоду часу; відстрочення строку погашення податкових зобов'язань.

Важливе значення при розгляді потенційно можливого розвитку санаторно-курортних закладів, як надавачів послуг, є вибір стратегії розвитку. Існують такі основні стратегії розвитку санаторнокурортних закладів [4]:

- стратегія кардинальної зміни - застосовується у разі зменшення завантаженості курорту, що вимагає з'ясування причин цього та пошуку методів підтримки здравниці з метою залучення суспільних і приватних інвестицій. При цьому можливий варіант перепрофілювання здравниці;

- стратегія збереження зростання, спрямована на підтримку низького рівня зростання за несприятливих зовнішніх умов, на залучення відпочиваючих завдяки введенню нових послуг (медичних і анімаційних);

- стратегія досягнутого зростання - застосовується для утримання досягнутого рівня у разі, коли курорт має у своєму розпорядженні лише обмежений набір нового продукту чи послуг і нездатний задовольнити новий ринок;

- стратегія вибіркового зростання, обрана курортом, орієнтованим на визначений сегмент ринку. Цей принцип розвитку припускає наявність двох компонентів: плану санаторно-курортного розвитку i структурного комплексу методу фінансової підтримки. Даний принцип застосовується при визначенні стратегії розвитку як конкретного закладу, так і галузі в цілому.

Висновки та перспективи подальших досліджень. 3 проведеного дослідження можна зробити наступні висновки. На сьогоднішній день ринок санаторно-курортних послуг України представлений широким спектром закладів, які спеціалізуються на різноманітних видах надання послуг. Однак проведений аналіз показав, що протягом 2010-2014 років в даній галузі спостерігаються негативні тенденції щодо зменшення, як кількості санаторно-курортних закладів, так і кількості споживачів їхніх послуг, що обумовлено рядом факторів. Попри це, ринок санаторнокурортних послуг України є потенційно привабливим, тому для його подальшого ефективного розвитку та максимізації використання його потенційних можливостей необхідним є впровадження і застосування ряду заходів. Тому дана тематика є актуальною та потребує подальшого дослідження.

\section{Література}

1. Вуйцик О. Роль і місце рекреаційно-туристичного комплексу в структурі економіки України / О. Вуйцик // Вісник Львівського університету. Серія Економіка. - 2008. - Вип. 39. - С.93. 
2. Про курорти : Закон України від 05.10.2000 №2026-III. [Електронний ресурс]. - Режим доступу : http://zakon5.rada.gov.ua/laws/show/2026-14

3. Офіційний сайт Державної служби статистики України. Санаторно-курортні та оздоровчі заклади [Електронний ресурс]. - Режим доступу : http://www.ukrstat.gov.ua/

4. Чорненька Н. В. Організація туристичної індустрії [Електронний ресурс] : Навчальний посібник / Н. В. Чорненька. - К.: Атіка, 2006.- 264 с. - Режим доступу : http://tourism-book.com/pbooks/book-39/ua/chapter$1935 /$

5. Воробйов Ю. М. Фінансове забезпечення розвитку санаторно-курортних закладів / Ю. М. Воробйов // Науковий вісник: Фінанси, банки, інвестиції. - 2012. - №3. - С. 47.

6. Давидова О. Ю. Дослідження факторів, що впливають на туристський попит в Україні / О. Ю. Давидова, І. В. Халіна // Коммунальное хозяйство городов: Науч.-техн. сборник. - 2006. - № 71. - С. 372-376.

7. Несторенко Т. П. Принципи формування цін на послуги закладів санаторно-курортної сфери [Електронний ресурс] / Т. П. Несторенко. - Режим доступу : http://www.readera.org/article/pryentsyepye-formuvannjatsin-na-posluhye-zakladiv-sanatorno-kurortnoye-sferye-10162927.html

8. Мігущенко Ю. В. Локальні туристично-рекреаційні комплекси як альтернативна модель активізації інвестиційної діяльності у туристичній галузі / Ю. В. Мігущенко // Стратегічні пріоритети. - 2008. - №3(8). - С. 168.

9. Зятковський І. В. Фінансове забезпечення діяльності підприємств : монографія / І. В. Зятковський. Тернопіль : Економічна думка, 2000. - 229 с.

10. Гуменюк В. В. Тенденції податкового регулювання ринку санаторно-курортних послуг в Україні / В. В. Гуменюк // Економіка розвитку. - 2014. - № 3. - С. 18-24.

Стаття надійшла 05.10 .15

Стаття прийнята до друку 20.10.2015

\author{
Коваленко Н.А. \\ кандидат технических наук, доцент \\ кафредра отельно-ресторанного бизнеса \\ Одесская национальная академия пищевых технологий \\ ул. Канатная, 112, г. Одесса, Украина, 65039 \\ E-mail: postfornatalia@gmail.com
}

\title{
АНАЛИЗ РЫНКА САНАТОРНО-КУРОРТНЫХ УСЛУГ УКРАИНЫ
}

Предметом исследования является анализ современных тенденций и значение деятельности рынка санаторно-курортных услуг в Украине. Цель исследования заключается в анализе современного состояния рынка санаторно-курортных услуг Украины, выявлении положительных и отрицательных тенденций на рынке, определении недостатков деятельности санаторно-курортных учреждений и предоставлении рекомендации по улучшению их работы в будущем.

Рассмотрена нормативно-правовая база, регулирующая рынок санаторно-курортных услуг в Украине. Приведена классификация санаторно-курортных учреждений по направлениям санаторнокурортной деятельности и их географического расположения. Проведено исследование тенденций изменения количества санаторно-курортных объектов и количества людей, прошедших лечение в этих учреждениях в течение 2010-2014 гг. В результате исследований установлено, что в этот период количественная характеристика рынка санаторно-курортных услуг имеет тенденцию к снижению. Выделена экономическая составляющая рынка санаторно-курортных услуг, показано влияние экономического эффректа исследуемого рынка на экономику государства.

На основе анализа выделены фракторы, которые сдерживают и стимулируют развитие рынка санаторно-курортных услуг. Предложены меры, которые позволят эфффективно использовать весь потенциал рынка санаторно-курортных услуг: для обеспечения рентабельности санаторно-курортных услуг следует применять постоянный мониторинг данных услуг, расширять существующий сегмент услуг; принимать во внимание и применять принципы стратегии ценообразования; разработать и осуществить мероприятия по привлечению инвесторов на рынок; использовать метод налоговых льгот для новых курортных объектов и потенциальных инвесторов, чтобы применить стратегию заведений санаторно-курортного хозяйства.

Результаты исследования могут быть использованы в разработке органами государственной власти программ развития рынка санаторно-курортных услуг Украины.

Ключевые слова: рынок санаторно-курортных услуг, санаторно-курортные заведения, финансовое обеспечение, инвестирование, налоговое регулирование. 


\author{
Kovalenko N.O. \\ Ph.D. in Technical Sciences, Associate Professor \\ Department of hotel and restaurant business \\ Odessa National Academy of Food Technologies \\ Kanatna str., 112 , Odessa, Ukraine, 65039 \\ E-mail: postfornatalia@gmail.com
}

\title{
MARKET ANALYSIS OF SANATORIUM AND HEALTH RESORT SERVICES IN UKRAINE
}

The subject of the study is to analyze current trends and identify market functioning spa services in Ukraine. The purpose of the study is to analyze the current state of the market of spa services in Ukraine, on which are detected positive and negative trends of the market, determined deficiencies of functioning spa facilities and provided recommendations to improve their work in the future.

To achieve this goal was used such methods of investigation: a systematic method - in writing all of the structural elements; comparative analysis - to assess the market of spa services, including institutions operating in the market and their activities; deductive - in the knowledge of the general laws of market process sanitary-resort in Ukraine; analysis - to assess the impact of institutional factors on the efficiency of the studied market; analysis and grouping - for processing, synthesis and analysis of factual material, determine market trends of spa services; using of graphs and tables - for visual presentation of the material; logical generalization of the results - in formulating conclusions.

Considered regulatory and legal framework, which regulates the spa services market in Ukraine. Conducted classification of establishments market spa service for directions of sanitation and their geographical location. Investigated the trend in the number of spa facilities and the number of people who made recovery in these institutions during 2010-2014, based on what was established that during the period quantitative characteristic market of spa services tends to decrease. Highlighted the economic component of spa services market, and given the economic effects of the investigated market on the economy of the state. Based on the analysis highlighted the factors that constrain and stimulate market development of spa services.

Offered a number of measures which allow effectively use all the potential of the market of spa services, namely: to ensure the profitability of spa facilities through continuous monitoring market spa services, expand existing service segment; to take into account the principles and apply pricing strategies; to develop and implement measures to attract investors to the market; to use the method of tax incentives for new spa facilities and potential investors to apply the strategy of institutions spa complex.

The results of the study can be used in the development of the public authorities of market development programs of spa services in Ukraine. regulations.

Keywords: market of spa services, sanatorium and resort facilities, financial support, investment, tax

\section{References}

1. Vuitsyk, O. (2008). Rol i mistse rekreatsiino-turystychnoho kompleksu v strukturi ekonomiky Ukrainy. Visnyk Lvivskoho Universytetu. Seriia Ekonomika., (39), 93-93

2. Pro kurorty : Zakon Ukrainy vid 05.10.2000 №2026-III. (2014, October 8). Retrieved October 17, 2015, from http://zakon5.rada.gov.ua/laws/show/2026-14

3. Derzhavna sluzhba statystyky Ukrainy. Sanatorno-kurortni ta ozdorovchi zaklady. (2014, August 18). Retrieved October 8, 2015, from http://www.ukrstat.gov.ua/

4. Chornenka, N. (2006, March 24). Orhanizatsiia turystychnoi industrii. Retrieved October 8, 2015, from http://tourism-book.com/pbooks/book-39/ua/chapter-1935/

5. Vorobiov, I. (2012). Finansove zabezpechennia rozvytku sanatorno-kurortnykh zakladiv. Naukovyi Visnyk: Finansy, Banky, Investytsii, (3), 47-47.

6. Davydova, O., \& Khalina, I. (2006). Doslidzhennia faktoriv, shcho vplyvaiut na turystskyi popyt v Ukraini. Kommunalnoe Khoziaistvo Horodov, (71), 372-376.

7. Nestorenko, T. (2014, December 23). Pryntsypy formuvannia tsin na posluhy zakladiv sanatornokurortnoi sfery. Retrieved October 8, 2015, from http://www.readera.org/article/pryentsyepye-formuvannja-tsin-naposluhye-zakladiv-sanatorno-kurortnoye-sferye-10162927.html

8. Mihushchenko, I. (2008). Lokalni turystychno-rekreatsiini kompleksy yak alternatyvna model aktyvizatsii investytsiinoi diialnosti u turystychnii haluzi. Stratehichni Priorytety, (3(8)), 168-168.

9. Ziatkovskyi, I. (2000). Finansove zabezpechennia diialnosti pidpryiemstv (p. 229). Ternopil: Ekonomichna dumka.

10. Humeniuk, V. (2014). Tendentsii podatkovoho rehuliuvannia rynku sanatorno-kurortnykh posluh $\mathrm{v}$ Ukraini. Ekonomika Rozvytku, (3), 18-24 